\title{
Of Constitutions, Campaigns and Commissions: A Century of Democratic Centralism under the CCP
}

\author{
Patricia M. Thornton ${ }^{*}$
}

\begin{abstract}
Democratic centralism, a hallmark of Leninist party organizations, has played a formative role in the history of the Chinese Communist Party (CCP). Yet despite being hailed as an "inviolable" and "unchanging" Party principle, understandings of democratic centralism have shifted dramatically over the century of its existence. This study traces the long arc of the concept's evolution across successive Party Constitutions, focusing on three critical historical junctures: the Sixth Party Congress, which formally adopted democratic centralism into its Constitution as an organizational principle; the Seventh Party Congress, which adopted rectification as the Party's practice of democratic centralism; and the 19th Party Congress, which set a new milestone in codifying the system as a disciplinary tool. I argue that while democratic centralism exemplifies the CCP's institutional plasticity and adaptive governance and is critical to understanding Party-driven constitutionalism in contemporary China, it also highlights an irresolvable paradox inherent in Party rule. Adaptability does not necessarily impart resilience. I conclude that the CCP's normatively unconstrained extra-constitutional leadership under Xi Jinping highlights the essentially and increasingly irrationalist aspects of its illiberal governance project.
\end{abstract}

Keywords: Chinese Communist Party; constitutionalism; party-state; Party history

Democratic centralism (minzhu jizhong 民主集中) is enjoying a revival in the Chinese Communist Party (CCP) under Xi Jinping 习近平. Whereas “intra-Party democracy" (dangnei minzhu 党内民主) and "collective leadership" predominated in the political discourse of the $\mathrm{Hu}$ Jintao 胡锦涛 era, Xi's top-level design (dingceng sheji 顶层设计) inclines strongly towards democratic centralism. For example, as Minxin Pei points out, the 2016 revision to "Several principles on political life in the Party" - one of the most important political documents issued by the post-Mao leadership - removed the section on

\footnotetext{
* University of Oxford, Oxford, UK. Email: patricia.thornton@politics.ox.ac.uk.
} 
"Adherence to collective leadership and opposition to personal arbitrary rule" (Jianchi jiti lingdao, fandui geren zhuandian 坚持集体领导, 反对个人专断) from the original 1980 document, replacing it with a discussion of "Adherence to the principle of democratic centralism" (Jianchi minzhu jizhongzhi yuanze 坚持民主集中制原则). The change, approved by the same Party plenum that designated Xi as the "core of the Party centre," subordinates collective leadership, one of the key commitments of post-Mao CCP governance, to a function of democratic centralism. ${ }^{1}$ As Holly Snape points out, in October 2020 the Politburo further broke with established precedent to approve a revised version of the "Central Committee work regulations" that emphasizes the exercise of what it refers to as "correct, effective centralism": in effect, a "new era" form of democratic centralism redesigned "to manipulate the dynamics of decisionmaking" at the uppermost echelons of the CCP under Xi Jinping. ${ }^{2}$

Months earlier, the Party launched a series of political education campaigns in which democratic centralism emerged as a recurrent theme. In February, the CCP General Office rolled out the "Two studies, one becomes" (liangxue yizuo 两学一做) campaign, insisting that Party members read the Party Constitution and embrace its undergirding principles, including democratic centralism, in order to become fully qualified CCP members. ${ }^{3} \mathrm{Xi}$ simultaneously issued "important instructions" for Party branch secretaries to measure themselves against the yardstick of Mao's 1949 "Party committee work methods" (dangweihui gongzuo fangfa 党委会的工作方法), “the core content of which is the strengthening of the system of democratic centralism." "Xi's October 2017 report to the 19th Party Congress then called upon the "key minority" (guanjian shaoshu 关键少数) of cadres in top positions to lead all members in upholding democratic centralism as laid out in the Party Constitution, disciplinary rules and regulations. ${ }^{5}$ More recently, in July 2019, the Party launched its "Never forget our original aspiration, remember our mission” (buwang chuxin laoji shiming 不忘初心 牢记使命) study campaign, pressing cadres and Party branches to return with new vigour to the study of core texts and core principles, including democratic centralism. ${ }^{6}$

1 Pei 2019.

2 Snape 2020.

3 "Zhonggong zhongyang bangongting yinfa 'Guanyu zai quanti dangyuanzhong kaizhan xue dangze danggui, xuexi lie jianghua, zuo hege dangyuan"” (CCP General Office publishes "On launching an education study proposal for all Party members to study the Party Constitution and its rules, study a series of addresses, and become a qualified [Party] member"). Xinhua wang, 28 February 2016, http://archive. today/dIbRu.

4 "Zhonggong zhongyang dangxiao, guojia xingzheng xueyuan, "Xuexi dangweihui de gongzuo fangfa" (CCP Central Committee Party School, National Academy of Governance "Study 'Party committee work methods'." Xuexi shibao, 29 February 2016, http://archive.today/pK9EJ.

$5 \mathrm{Xi} 2017$.

6 “Zhongyang, 'bu wang chuxin, laoji shiming' zhuti jiaoyu lingdao xiaozu yinfa 'gongzuo fang'an' duizhao dangzhang dang gui zhao chaju" (CCP Central "Never forget the original intention and always remember our mission" education leading group issues "work plan" in respect to gaps in Party rules and regulations), 22 July 2019, http://archive.today/ZdD2j. 
As Andrew Mertha, Ling Li and Samson Yuen all separately note, the study campaigns and disciplinary efforts behind Xi's quiet revival of democratic centralism resemble those of the Yan'an 延安 era, suggesting a link between the principle's resurgence and the disciplinary practices of cadre study and rectification, a connection first made by Mao himself. ${ }^{7}$ In the section of his 1938 report to the Party Central Committee on Party discipline, Mao asserted that only democratic centralism made it possible "to unite the whole Party, overcome new difficulties, and obtain new victories," and defined its "concrete application" in terms of the now classic “four obediences" (sige fucong 四个服从): “the individual is subordinate to the organization; the minority is subordinate to the majority; the lower level is subordinate to the higher level; and the entire membership is subordinate to the Central Committee." 8 Violations of this chain of subordination, Mao declared, were "intolerable" and "did great damage to the Party's unity and to the Party's revolutionary struggle." Mao elaborated further in his discussion of Party education, arguing that study campaigns were necessary "so that Party members can understand what is meant by democratic life, what is meant by the relationship between democracy and centralism," and how "democratic centralism should be put into practice" to avoid dangerous "ultrademocracy" and "laissez-faire" practices running rampant. 9

Although only adopted into the Party Constitution in 1927, democratic centralism has been with the CCP in some form for the entirety of its existence, introduced into Chinese political discourse by Soviet advisors and Chinese intellectuals returning from study abroad. The term first appeared in prerevolutionary Russia in separate 1905 resolutions put forth by the Bolshevik and Menschevik factions to guarantee the participation of Russian Social Democratic Workers' Party (RSWDP) members in discussion and debate and the right to elect and recall party officers. By 1921, however, in the hands of the Bolsheviks, democratic centralism became more closely associated with the imposition of "iron discipline" from above than with the broadening of participation from below. Although the Communist International (Comintern) made acceptance of democratic centralism a requirement for all member organizations in $1920,{ }^{10}$ it took the CCP a full seven years to comply. ${ }^{11}$

Clearly ambivalent about its adoption, early CCP leaders beginning with Mao refashioned the concept's meaning and context, and the scope of its application, over time. Far from the "fundamental" (genben 根本), “foundational" (jiben 基本) or “unwavering" ( $b u$ yaodong de 不摇动的) constitutional principle proclaimed in Party documents, I argue that democratic centralism represents an example of the CCP's institutional plasticity and adaptive governance across five

\footnotetext{
7 Mertha 2017; Li, Ling 2019, 49; Yuen 2014.

8 Mao 1938, 532.

9 Ibid., 534.

10 Waller 1981, 21-24, 31, 34, 42.

11 van de Ven, 1992, 126-131.
} 
generations of Party leadership ${ }^{12}$ and is critical to understanding Party-driven constitutionalism in contemporary China. Tracing the long arc of the concept's evolution across successive Party Constitutions (dangzhang 党章), I focus on three critical historical junctures that illustrate its malleability over the century of the CCP's existence: the Sixth Party Congress (1928), which formally adopted democratic centralism as an organizational principle into the Party Constitution; the Seventh Party Congress (1945), which introduced cadre rectification and the mass line as key components of the practice of democratic centralism; and the 19th Party Congress (2017), which set a new milestone in codifying the system as a disciplinary tool. As I argue below, the history of democratic centralism in China forms part of the "social intertexture" of the party-state's governance model, ${ }^{13}$ spanning the Party's more formalized institutions (congresses, plenary sessions, organizational meetings) and less structured Party practices (cadre rectification, criticism/self-criticism, study programmes), as well as Party and state hierarchies. The system of "fragmented authoritarianism," composed of vertical (tiao 条) and horizontal (kuai 快) power relations within the state, ${ }^{14}$ is interpenetrated from top to bottom by the Party, not only by means of the Party-controlled system of appointments (bianzhi 编织) but also by means of the insertion of Party organizations directly into the state structure through which the Party exercises control over the state. ${ }^{15}$ Democratic centralism thus works across Party and state, serving as a constitutionally enshrined principle, an established political practice and, more recently, as an increasingly elaborate disciplinary system through which the Party now governs under "socialist rule of law." According to Zhai Han, the constitutional entrenchment of democratic centralism is critical to the "relationship between the CCP and the People's Republic in forming a one-party state," constitutionally securing the stability of the political structure of both Party and state from the revolutionary to the reform eras. ${ }^{16}$ At the same time, as I will also show, democratic centralism has chiefly proved useful to the Party precisely because of its ambiguity: it works as a tool for policing political, rather than purely organizational, control. As such, it highlights the ultimately irresolvable contradictions between the political and rational bureaucratic imperatives of the CCP party-state.

\section{The Constitutional Order of the Chinese Party-state}

Rejecting mainstream claims that China has "a constitution without constitutionalism," Jiang Shigong recently proposed that any understanding of "China's reallife constitutional spirit, institutions, and conventions" must break free from the "formalistic shackles of the written constitution" to consider fully "the party's

12 Heilmann and Perry 2011.

13 Shue 1990, 4.

14 Mertha 2005; 2009.

15 Brødsgaard 2002.

16 Han 2020, 215. 
constitution, constitutional conventions, constitutional doctrine, and constitutional statutes." 17 These four sources, which comprise China's "unwritten constitution," are in some cases "more significant than the written constitution" and qualify China as a constitutionalist state, albeit one that rejects the liberal underpinnings of the Western model. Larry Catá Backer agrees, arguing that the essence of Chinese constitutionalism is specifically party-state constitutionalism, the key to which is the separation of the Party from the state apparatus. The Party exercises an unchallenged monopoly of political authority and retains the power to deliver definitive decisions on political issues, whereas the state apparatus chiefly acts as the implementer of the Party's decisions. ${ }^{18}$ Jiang asserts a clear distinction between the state (xianfa 宪法) and Party constitutions (dangzhang 党章), arguing that they are "two completely different concepts" with "disparate connotations" and distinctly different etymologies in Chinese. ${ }^{19}$ Backer, by contrast, treats both as mutually complementary, with one laying out the organization of the state apparatus, and the Party constitution organizing and institutionalizing the supreme "manifestation of political authority within the nation," which is "collective, corporate and is expressly bound by rules and norms that give character to that polity." 20 More recently, Jiang has proposed that the Party constitution not only takes precedence over the state constitution, but as it is both "higher" and "greater' than the Party itself, it is capable of containing CCP's routine exercise of power. ${ }^{21} \mathrm{Xu}$ Xianming goes even further in asserting the absolute supremacy of the CCP, claiming that the Party is simultaneously "in the centre of the law, under the law, and above the law," 22 hailing it as a neo-Hobbesian "virtuous Leviathan."23

But is the exercise of a political leadership that is meant to transcend laws, by democratic centralist or other means, beholden to the law, or even a rules-based order? For Stephen Angle, the determination of whether China's adherence to democratic centralism can be considered just, or "decent" in the Rawlsian sense, is partly dependent upon the genuineness of the CCP's commitment to the rule of law. ${ }^{24}$ By contrast, both Jiang and Backer agree that the relationship between the Party and the reform-era state has been institutionalized beneath a single, unified constitutional framework. ${ }^{25}$ Xiaodan Zhang refers to this position as “political constitutional theory” (zhengzhi xianfaxue 政治宪法学), an approach that invokes the uniqueness of the Chinese system in order to assert a normative justification for the superiority of the Party over the state and, 
therefore, the superiority of the Party constitution over that of the state. ${ }^{26}$ For Backer, constitutional analysis in China ought to focus on the Party constitution and its internal ordering of values and principles in order to understand the functioning of the political system as a whole. ${ }^{27}$ As Flora Sapio observes, foundational constitutional principles like democratic centralism "produce their effects throughout the entire political and legal system. The creation of a new principle, its ingress in the Constitution, its re-interpretation or its fall into disuse will cause consequences as concrete as the changes in established institutions, in legislation, and in its enforcement." 28

Ling Li likewise adopts the positivist orientation shared by Jiang and Backer, yet is more sceptical about the constitutional separation between Party and state. ${ }^{29} \mathrm{Li}$ argues that since the initiative to distinguish between their functions (dangzheng fenkai 党政分开) during the 1980s was reversed in the wake of the Tiananmen Square crackdown, the Party has moved overwhelmingly to interpenetrate the state apparatus, constructing an interlocking directorate through the mechanism of the nomenklatura system and the formation of Party groups comprising all Party members who hold executive office within an organization. As collective decision-making bodies, Party groups "are subject to 'democratic centralism'," which in practical terms means that key "decisions need to be deliberated and reached collectively, in which circumstances majority opinion rules," giving the Party a potential hedge against arbitrary decision-making and the abuse of power. ${ }^{30}$ However, unlike the separation of powers in Western political systems, the covert dual role of the Party-group system "helps to veil the Party's footprints when it penetrates state power." 31 Although an initial attempt was made to reduce the importance of Party groups in the 1987 Party Constitution, a post-1989 volte face saw the Party-group system greatly reinforced. Party groups have since been tasked with converting and operationalizing Party decisions into state decisions, operationally but obliquely turning the state into the Party's agent. The bifurcation of power between the two and its concealment, $\mathrm{Li}$ argues, serve as powerful tools for the CCP, allowing backstage collective discussion and debate horizontally among Party group members while also ensuring the verticality of decision-making power through the exercise of centralism beneath the aegis of the Party. ${ }^{32} \mathrm{Li}$ and Wenzhang Zhou together have since proposed that what Chinese constitutions fail to address may serve as a more potent tool for Party leaders than the laws and regulations they enumerate: their opacity creates a "constitutional vacuum" that provides those in power with the

26 Zhang, Xiaodan 2019; Yu Keping and others who reject "political constitutionalism" argue that the implementation of "democratic centralism" produces an instrumentalist and "deficient" form of democracy in China. Yu 2010, 4-5.

27 Backer 2009, 154.

28 Sapio 2015, 11.

29 Li, Ling 2015.

30 Ibid., 101.

31 Ibid., 96.

32 Ibid. 
maximum flexibility to operate with the fewest constraints from external forces. Fundamental issues of governance are thus kept out of Chinese constitutions, allowing the Party the prerogative to address them outside of the constitutional realm. ${ }^{33}$

The Party constitution, which has normative superiority to that of the state, therefore instantiates a paradox. The National Party Congress, as the CCP's "highest decision-making body," retains the sole constitutional authority to make, remake and amend the Party constitution, and nearly every Party Congress in the Party's history has prominently placed amending its constitution on its agenda. Yet, in practice, the Party Congress has never been permitted to fulfil the constitutional authority allotted to it by its own constitution; in actuality, it does not make its own decisions but instead endorses the incumbent Party leadership's resolutions. "The fascinating secret of the Party Congress," Guoguang Wu notes, "lies in its strange combination of political hollowness and institutional holiness," marked by a gap between the CCP's stated constitutional norms of representation, inclusion and participation under democratic centralism, and its actual political practice. ${ }^{34}$ Despite this "political hollowness," or perhaps because of it, the Party Constitution retains ultimate normative power to the point that even Mao himself once brandished a copy of the Eighth Party Constitution at a December 1964 Central Working Conference, claiming that it protected his "freedom of speech": "Don't contradict the laws which you yourselves have adopted but which you don't follow," he harangued those in attendance. $^{35}$

The long arc of the CCP's engagement with democratic centralism - from constitutionally enshrined principle, to semi-formalized political practice, to an increasingly institutionalized disciplinary system supported by elaborate legal frameworks - thus persistently reproduces the paradox of illiberal governance. What Frank Pieke has dubbed the "sacred void" at the centre of the party-state's constitutional order actively resists the scrutiny of mass supervision and transparency, beneath an ever more elaborate legal and regulatory architecture that is designed to preserve, but more generally to obfuscate, the Party's exercise of power. ${ }^{36}$

\section{Early origins: Democratic Centralism as Principle}

As noted above, although the earliest CCP leaders were familiar with the concept of democratic centralism, the principle was not formally adopted into the Party Constitution until the Fifth Party Congress in 1927. As early as February 1921, Chen Duxiu 陈独秀 drafted a document advocating a system of centralized 
power (zhongyang jiquanzhi 中央集权制) for the Party. Li Da 李达 disagreed vehemently, proposing a structure that divided power among the localities (difang fenquan 地方分权) instead. ${ }^{37}$ This lack of unity persisted through the First Congress, with the first CCP members expressing reluctance to subordinate themselves to the "iron discipline" of the Comintern's authority. Zhang Guotao 张国奉, who chaired the meetings and favoured a more centralized organization, blithely reported that the Common Programme was adopted following "democratic discussion, [with] the minority giving way to the majority, and subordinate giving way to superordinate members." 38 Delegate Cheng Gongbo 陈公博, however, noted that the proposed amendment on Party organization had been so contentious that a decision had to be deferred until the following year. ${ }^{39}$

Chen Duxiu's arrest in October 1921 broke the logjam; when Comintern agent Maring bailed him out of prison, an agreement was struck that the CCP would accept democratic centralism, a measure that was voted through at the Second Party Congress in 1922 with a copy of the Comintern's Articles of Association attached to the resolution. However, with regionalist resistance again on the rise, the Third Party Congress declined to draft an amendment formalizing its adoption. Months before the Third Congress met in March 1923, Comintern agent Sergei Dalin complained:

Matters are discussed without a chairperson or secretary and everyone speaks whenever they like or feel it necessary. Only on the following day does the secretary record decisions in the minute book. Having talked for hours it seems as though they are just about to reach a final decision when suddenly someone slaps down a small amendment, which touches on no issue of principle, and everything is once again thrown into disarray, matters of substance as well as amendments. ${ }^{40}$

The Third Congress established a Central Executive Committee and a permanent Central Bureau (zhongyang ju 中央局) in June 1923; the Fourth created a central Party Organization Department. Neither congress adopted democratic centralism. It was only after the Fifth Party Congress in April 1927, when Chen Duxiu came under serious criticism, that the term "democratic centralism" was finally drafted into the Party's Constitution by the Politburo in June, the only constitution in the Party's history not to have been adopted by the Congress. Article 12, appearing in the section on Party building, tersely acknowledged democratic centralism as the "guiding principle" (zhidao yuanze 指导原则) for Party departments (dangbu 党部). Final decision-making authority was vested with the Comintern, which suspended Chen Duxiu the following month and transferred his responsibilities to Qu Qiubai 翟秋白, before organizing a Sixth Party Congress to take place near Moscow.

The Sixth Party Constitution for the first time formally recognized democratic centralism as the Party's “organizational principle" (zuzhi yuanze 组织原则), 
applying it to all Party organizations, in line with the Soviet Communist Party Constitution. More importantly, it elaborated three further guidelines for enacting democratic centralism within the Party: first, officeholders of Party departments at all levels were to be elected; second, all Party departments were to report regularly to the members who appointed them; and third, although the right to free and open debate among Party members was secured, the Constitution stipulated that once a resolution was adopted, all members must execute it unconditionally, a provision that exceeded even the instructions laid out in the Soviet Communist Party Constitution at the time. The Sixth Congress's formulation thus subordinated "democracy" to "centralization," ensuring that the principle of democracy could not override, or even interfere with, the exercise of centralized power moving forward. The chief justification for doing so was, unsurprisingly, the breakdown of the First United Front between the CCP and ruling Nationalist Party, but the subordination persisted well beyond that critical period. ${ }^{41}$

In June 1929, the Sixth Central Committee's Second Plenary returned again to the principle of democratic centralism, and the confusion over how - in practice the CCP might balance the contradictory elements of democracy with centralization. A resolution on organizational questions was passed by the plenum to "establish correct democratization within the Party," emphasizing that it must be restricted to the Party and adapted to the particular conditions in which the CCP found itself in 1929. The relatively weak position of the proletariat placed the revolutionary viewpoint of the majority of members in a fragile state, and most suffered from a "low political level." Therefore, under the existing conditions of "white terror," "the resolutions of the highest organ should be unconditionally implemented by the lower-level organs." The resolution concluded that it was necessary to "democratize life within the Party, but [only] under centralized guidance," setting forth a long-term pattern of narrowing the scope of free debate within the Party, and confining items of discussion to matters of Party strategy. ${ }^{42}$

\section{Rectification: Democratic Centralism as Practice}

The gap between the Sixth and Seventh Party Congresses in April 1945 was the longest in the CCP's history, despite the passage of Politburo resolutions in December 1937 and March 1938 to convene the next Party Congress "in the near future." 43 The Party's ranks exploded in the interim. Although the CCP had been literally decimated over the course of the Long March, membership surged in Yan'an, including large numbers of self-described peasants and many new members with "intellectual" and "bourgeois" backgrounds. Whereas the

$41 \mathrm{Xu}$, Tiancheng 2019, 10-11.

42 Ibid., 11-12. These unresolved tensions would return, politically and conceptually, in the 1950s following Stalin's death.

43 Gao, Mosher and Guo 2018, 176, 183. 
Sixth Party Congress was attended by 118 delegates representing a total of nearly 13,200 CCP members, by 1945 membership had swelled to 1.21 million, requiring 752 delegates to represent the membership at Congress. Thus, if democratic centralism had in theory meant open and unrestricted debate on key issues in the past, the anticipated size of the Seventh Congress posed clear logistical challenges. ${ }^{44}$ Moreover, these were challenges that Mao would need to navigate carefully in order to protect his dominant position: although the Sixth Plenum in 1938 witnessed Moscow's endorsement of Mao's leadership over that of his rival Wang Ming 王明, he continued to face the possibility of resistance, particularly from among those in the student group returned from Russia. Since his usurped rival retained his seat on the Party Secretariat, Mao had to consolidate his advancement with care.

Mao faced challenges to his dominance on more than one front. Democratic centralism as adopted by the Sixth Congress vested final authority in Moscow, with the Sixth Party Constitution rendering the CCP subordinate to the Comintern. Mao's emergence at the 1935 Zunyi Conference 遵义会议 signalled a shift that was strengthened further by the Sixth Plenary in 1938, which endorsed the "sinification of Marxism" under Mao's stewardship. The September-October 1941 enlarged Politburo meeting agreed to establish a senior cadre study group, reorganize the Central Party School, and create committees to "clarify Party history" and review underground CCP work in "white areas," all under Mao's direction, giving him the power to craft the central narrative (koujing 口径) around which Party members would be expected to conform. This process of not merely synthesizing a distinctly Chinese version of Marxism but also of unifying the membership around the core, was central to the emergence of "hierarchical democracy," which would come to define the vastly expanded Party ranks. ${ }^{45}$

The Yan'an Rectification Movement, which began in earnest in 1941, was partly launched as an effort to train new Party members and transform their worldviews. In one 1942 letter, Mao remarked that "to control the ideological leadership (zhangwo sixiang lingdao 掌握思想领导) is the first step in controlling everything in the leadership," and that "the implementation of thought control means the education of cadres." 46 “One delegate, Ma Wenrui 马文瑞, recalled that the Party Congress had been delayed because Mao believed that only through rectification could comrades be made clear about the correct political line that would allow the Congress to run well." 47 Another delegate reflected, "the perfect success of the 7th Party Congress would not have been achieved if there had not been this campaign of study and rectification." 48

It began with a series of speeches launched by Mao in 1942 calling for the correction of poor "work styles" in the Party. A far-ranging study campaign 
followed that targeted intellectuals, journalists and ordinary cadres in all work units, who were expected to read and discuss speeches and essays by Party leaders, tracts on CCP history, other selected material carefully curated by Mao, and key Central Committee resolutions. Collectively, the core cannon was referred to as the "Twenty-two documents" and participants kept mandatory selfreflection journals as they worked their way through the corpus. Study sessions were combined with gruelling rounds of criticism and self-criticism, in some cases culminating in public humiliation sessions to pressure confessions from "guilty" perpetrators. These high-stakes tactics were made even more intense during the "emergency rescue" campaign, which was coterminous with the dissolution of the Comintern in May 1943 and was designed to extract all and any useable intelligence from intellectuals and cadres who had previously worked in "white areas" prior to their arrival in Yan'an. Suicides were not uncommon. However, the carefully calibrated process of rectification produced a collective experience that proved cathartic for many and forged powerful bonds among those who survived. ${ }^{49}$

By the time of the Seventh Party Congress in 1945, the Party had been thoroughly transformed, as had the practice of democratic centralism within the CCP. Whereas during previous national congresses the practices of debate, voting and resolution had epitomized democratic centralism, the Seventh Party Congress "overthrew this model by making the rectification campaign the highest form of democratic centralism within the Party." 50 Thus,

The Party Congress became the result of rectification. When differences of opinion arose within the Central Committee, the process of democratic centralization had to be completed before the Congress could be held, and congresses could be legally postponed if the Central Committee was not unified in its thinking ... democratic centralism within the Party before the Rectification Campaign usually adopted the debate-vote model (biaojue 表决), but this model was replaced with a discursive process in which a core (hexin 核心) is first established within the Party centre, and then a consensus is built up through study to confirm the mainstream view. ${ }^{51}$

This was reflected in the Seventh Party Constitution, which set aside the term "democratic centralism" (minzhu jizhong) in favour of two formulations: the "centralization of democracy" (minzhu de jizhong 民主的集中) and a “democratic centralist system” (minzhu de jizhongzhi 民主的集中制), described as "centralism on the basis of democracy and democracy under the guidance of centralism." 52 This was to be achieved through the "four obediences" and Party discipline, a theme stressed repeatedly throughout the document. In his 60,000-character report to the Congress on the constitutional revisions, Liu Shaoqi 刘少奇 on four occasions stressed that the practice of rectification had succeeded in "unifying the entire Party, ideologically, politically and organizationally as never before," having eliminated "erroneous thought lines" 
"opportunist lines" and "non-proletarian ideology." The "rightist opportunist line of Party organization" was singled out for particular scorn for having attempted to turn the Party into "a petty-bourgeois liberal party," undermining the "democratic centralist system" and "iron discipline." 53 Rectification had eliminated the need for substantive disagreement and debate, leaving the National Congress to serve as a ritual of performative unity.

This new understanding of democratic centralism as the practice of achieving the absolute unification (yi yuanhua 一元化) of thought through rectification thereby mitigated the need for open collective debate. ${ }^{54}$ It was recorded in the Seventh Party Constitution's declaration that the CCP was a "united combat organization" (tongyi zhandou zuzhi 统一战斗组织) whose strength resided in its "unity of will and action." In acknowledging rectification as democratic centralism in practice, the Seventh Party Constitution affirmed that the Party must always remain attentive to clearing its own ranks of those who would "destroy the Party's programme, the Party Constitution, and Party discipline, and moreover who cannot be rectified (buneng gaizheng 不能改正).”

Once the CCP assumed national power, this new practice of democratic centralism as rectification was expanded to mass organizations, linked to what Mao referred to in 1962 as "the method of criticism and self-criticism." 55 The drive to "unify thought" outside the boundaries of the Party ranks coincided with mass campaigns aiming to resolve contradictions among the people, basically bringing to an end the practice's more democratic elements in favour of its centralizing tendencies by $1957 .{ }^{56}$ Frederick Teiwes notes that while the practice of democratic centralism within the ranks of the Party continued, albeit sporadically, up to the beginning of the Cultural Revolution, Mao's unpredictability and the eroding consensus over organizational norms rendered the process increasingly dysfunctional and ineffective. This persisted until the 11th Party Constitution's definitive declaration that, moving forward, centralism would be more important than democracy in restoring Leninist discipline in the CCP. 57

\section{Party Discipline: Democratic Centralism as System}

Although democratic centralism had been described as a system ( $z h i$ 制) as early as the Fifth Party Constitution (1927), its fuller integration into the Party's disciplinary and legal apparatus has made a remarkable transformation under Xi Jinping, whose leadership has seen a vast effort to standardize and institutionalize the Party's governance role through top-level design. Prior to that time, compliance with the patchwork of Party rules and regulations - including those involving democratic centralism, either in principle or in practice - was overseen by a 
hodgepodge of institutions. The Fifth Party Congress established the first centralized, albeit extraconstitutional, Party disciplinary body: the Monitoring and Inspection Commission (jiancha weiyuanhui 监察委员会, MIC hereafter). Within months, however, after nearly all of its members were eliminated by the Nationalist Party, the organization largely disappeared from the historical record. A variety of successors oversaw relatively narrow types of cadre activity during the 1930s and 1940s. In 1945, the Seventh Party Congress introduced an ad-hoc version of the former centralized MIC into the Party Constitution, to be convened if and when the Party's Central Committee "deemed necessary"; it operated as an enforcement arm of the Party until the Ninth Party Congress removed the provisions governing MICs from the Party Constitution in 1969. ${ }^{58}$

The Ninth Party Constitution (1969) also saw major amendments to the articles dealing with democratic centralism. It was the first constitution to afford the masses outside the Party an explicit role in supervising Party members and cadres. Party members were not only granted the right to offer suggestions and criticisms to leaders "at all levels" but were also permitted to express their reservations directly to the Central Committee and the chairman, if they so chose. Further language was added in 1973 warning Party members and cadres against suppressing criticism and minority opinion and seeking retribution. These injunctions were not only preserved in the 11th Party Constitution in 1977 but, in the wake of the "line struggles" of the Cultural Revolution, were further elaborated, affirming the right of all to air views fully without fear of reprisal. In his report on revising the Party Constitution to the 11th Congress, Ye Jianying 叶剑英 asserted that both the provisions guaranteeing open debate within the Party and the restitution of institutionalized Discipline Inspection Commissions (jilü xiancha weiyuanhui 纪律检查委员会, DIC hereafter), which were originally established in 1949 but were largely dormant during the tumultuous campaigns of the Mao era, were crucial in restoring democratic centralism. ${ }^{59}$ This assertion marked the initial steps towards standardizing democratic centralism as an institutionalized system in the post-Mao era.

In December 1978, the Third Plenum elected 100 Party members to serve on the newly reinstated Central Discipline Inspection Commission (Zhongyang jilü xiancha weiyuanhui 中央纪律检查委员会, CDIC hereafter); after revising and consolidating the institutional structure of the DICs in 1982, the 12th Party Congress presented the Party's reworked disciplinary apparatus as "a complete system from top to bottom, and its jurisdiction is greatly strengthened compared to the past." The goal of the new system was nothing less than a complete overhaul of Party work styles and organizations in the style of the Yan'an Rectification, an overhaul capable of restoring absolute political unanimity under the Party Central Committee as the distillation of democratic centralism 
in practice. ${ }^{60}$ The CDIC initially undertook the drafting of the "CCP disciplinary regulations (for trial implementation)" (Zhongguo gongchandang jilü chu fen tiaoli (shixing) 中国共产党纪律处分条例 (试行)) in March 1988. The trial document was approved by the Party Central Committee nine years later, in 1997. Article 46 identified violations of democratic centralism as "refusals to implement, or the arbitrary revisions of a decision on a major issue made by a Party organization, or departures of that decision by an individual or small group, causing either failure or loss of work outcomes." Article 6, however, stipulated that Party branches or organizations determined whether or not a member had committed a violation, not the DICs. ${ }^{61}$ A further revision in 2003 removed the language regarding the failure or loss of work outcomes, but added that disciplinary decisions made by higher-level Party organizations against individuals or subordinate branches must be implemented. ${ }^{62}$

Both the substance of and procedure for handling Party disciplinary violations have changed under $\mathrm{Xi}$, who has advanced vigorously not only the compilation of new Party regulations but also the process of closing the gap between Party rules and state law, arguably reversing the "turn against the law" of his two predecessors. ${ }^{63}$ Furthermore, Xi's institutionalization of regulatory, disciplinary and legal frameworks has been far-reaching: the 2014 "Decision concerning certain major issues in comprehensively moving forward ruling the country according to law" laid out a definitive constitutional order for the country that explicitly placed the Party at the helm of not only the process of deepening reforms but also all state affairs. The 2014 "Decision" pointed out that "governance according to the law requires that the Party govern the country on the basis of the Constitution and the laws and requires that the Party manages and governs [itself] according to intra-Party regulations." Furthermore, the Party must oversee the implementation of "democratic centralist procedures" throughout the party-state structure in order "to safeguard the authority of the centre and unity of the entire Party and country." The 2014 "Decision" also directed the Party to "pay attention to linking and coordinating intra-Party regulations with state laws." Speaking on behalf of the Politburo, Xi explained that "to comprehensively move ruling the country according to the law forward, we must strive to create a structure in which state laws and regulations, and intra-Party laws and regulations, are mutually complementary, stimulate and guarantee each other." 64

Democratic centralism, as a means for preserving the Party's ability to guarantee unconditional obedience to its political line, has figured prominently in the

60 Young 1984, 49-52.

61 "Zhongguo gongchandang jilü chu fen tiaoli (shixing)" (CCP disciplinary regulations (for trial implementation), 1997, http://archive.today/Oih7c.

62 "Zhongguo gongchandang jilü chu fen tiaoli" (CCP disciplinary regulations), 2003, http://archive.today/ NZy2Q

63 Pei 2019; Zhang, Taisu, and Ginsburg 2019, 312.

64 Xi 2014. 
flurry of rule- and regulation-making that has unfolded since. The CCP disciplinary regulations underwent a major revision in 2015, adding provisions that made "intentionally evading collective decision-making, making decisions on major issues, and the appointment and dismissal of key cadre posts" without proper consultation, and the changing of "key project arrangements and the use of significant funds" without following the proper procedures regarding consultation and collective decision-making all punishable offences. ${ }^{65}$ Following the 19 th Party Congress's establishment of the National Supervision Committee (Guojia xiancha weiyuanhui 国家检查委员会, NSC hereafter) in October 2017, the Party's DICs were further integrated with the national organs of political power, conjoining them as a single party-state organ working jointly with "combined offices and posts" (heshu bangong 合署办公). The new system has vastly broadened and strengthened the Party's anti-corruption work at all levels and has greatly increased the numbers of officials under supervision (according to one recent report, by as much as four-fold in Beijing). ${ }^{66}$ It has also politicized anti-corruption and supervision efforts, vowing to "place the political before anything else" and "not lose sight of the forest for the trees."67

These broader trends are somewhat borne out in the Bashou database (bashou anli 把手案例), which lists 13 court judgments issued between 2014 and 2019 in which either violations of the principle or system of democratic centralism have played a role. ${ }^{68}$ Three of the mentions occur in criminal cases, ten appear in civil cases; all are in the context of charges brought against cadres or Party branches accused of various infractions. Although the overall number of cases is still too small to draw meaningful inferences, those citing violations of democratic centralism (nine of which cite violations of principles of the democratic centralist system) have risen year on year.

The scope of democratic centralism has been reasserted over state officials as well. Article 15 of the 1949 Common Programme stipulated that "democratic centralism shall be practised in the organs of state power at all levels," a claim restated in Article 2 of the 1954 State Constitution. ${ }^{69}$ This has been reinforced with new legal frameworks introduced in the Xi Jinping era. In June 2020, the National People's Congress (NPC) Standing Committee further promulgated a national administrative discipline law for public officials explicitly clarifying that violations of democratic centralism apply to all state employees, whether or not they are not Party members - all infractions are punishable by warning,

65 “Zhongguo gongchandang jilü chufen tiaoli" (CCP disciplinary regulations), 2015, http://archive.today/ XNP8s.

$66 \mathrm{Li}, \mathrm{Li}$, and Wang 2019.

67 Nie 2017.

68 https://www.lawsdata.com/, a platform compiled using "crawler software" to extract data and delete duplicate judgments from the China Judgments Online database (http://wenshu.court.gov.cn). Yang 2019, 78.

69 And in Article 3 of the 1982 Constitution. Han 2020, 210. 
demerit or removal from office. ${ }^{70}$ Less than a year later, in March 2021, the NPC also amended its Organic Law, reiterating its complete subjection to the principle of democratic centralism, in the name of giving "full play to democracy" but also to "the collective exercise of power." 71 As one observer noted, in so doing, the NPC brought to a formal and decisive end even the modest experiment in representative democracy suggested in the 1982 Constitution, which nominally designated the NPC as "the organ through which the people exercise state power" in order to "secure their role as the masters of the state," albeit under CCP leadership. ${ }^{72}$

\section{Adaptation and Extra-Constitutional Prerogative Power}

Clearly, the CCP has proved a resilient and adaptive political party which has survived the transition from a revolutionary to a consolidated governing organization. As I have argued, the evolution of democratic centralism, from principle to practice to integrated disciplinary system, is illustrative of the adaptability and institutional plasticity of the constitutional order of the party-state and highlights how the CCP has expanded and consolidated its reach beyond its core membership over time. Arguably, democratic centralism can be read as a bargain struck within the ruling coalition, offering member stakeholders a measure of participation in decision making in return for unquestioning obedience, as well as a rulebased method for managing and stabilizing potential dissension within the CCP's ranks. Martin Dimitrov has recently proposed that the resilience of communist parties lies in adaptations that expand a regime's support base beyond the selectorate - defined as that group of power holders that elects those in the winning coalition, which in turn selects the Party leader - that generate regime legitimacy through institutions of horizontal and vertical accountability. ${ }^{73}$ Certainly, the CCP's initial adoption of democratic centralism within the ranks of the selectorate provided horizontal accountability within the ranks of the Party and vertical accountability with respect to the Comintern. Yet, as I have shown, with the dissolution of the Comintern in 1943, the principle became a disciplinary practice that aimed at selective inclusion and absolute unification and subordinated the expanding Party ranks to the political will of the Party leadership during the Yan'an era. The extension of the participatory elements of that practice to those outside the Party through mass supervision, which arguably afforded a measure of accountability to the people at large, represented a brief constitutional experiment that did not long outlive Mao himself. Democratic centralism's reinvention under China's "turn towards law" under Xi has further widened

70 Zhonghua renmin gongheguo gongzhi renyuan zhengwu chufen fa (Law on Administrative Discipline for Public Officials), 6 June 2020, http://archive.today/xwpwO.

71 "Quanguo renmin daibiao dahui guanyu xiugai 'Zhonghua renmin zhongheguo renmin daibiao dahui zuzhifa' de jueding" (Decision of the NPC on revising the Organization Law of the NPC). NPC, 11 March 2021, http://archive.today/qBtPr.

72 Peng 1982; Bai 2021.

73 Dimitrov 2013, 6. 
the Party's scope both to police administrative compliance within the governing apparatus and to control local agents. ${ }^{74}$

While these successive reinventions may demonstrate the Party's adaptability, adaptation does not necessarily equate to resilience. ${ }^{75}$ It remains to be seen if Xi's reliance on democratic centralism to enforce a more fully institutionalized constitutional order will stabilize the regime over the longer term. The CCP's increasingly technocratic illiberal constitutionalism represents a paradoxical attempt to reserve a hypothetical space for the Party, unfettered and unconstrained, at the core of a vast and proliferating architecture of socialist legality. Individual CCP members and branches are subordinate to both Party rules and state laws, but the unitary will of the Party remains sovereign outside, or above, that framework. Whether one identifies this paradox as a "strange combination of political hollowness and institutional holiness,"76 a "zone of lawlessness,"77 or a "constitutional vacuum," 78 the Party's normatively unconstrained political leadership highlights the essentially irrationalist aspects of its illiberal governance project. As Samuli Seppänen points out, "'the Party' may be above the law, but is 'it' also above its own regulations?"79 Constitutionally, this paradox refracts down to the level of the individual: in their capacity as CCP members, state officials should observe the Party's decisions, whereas in their capacity as state employees, the same officials are mandated to represent the interests of the people. It also throws into question where ultimate sovereignty resides, and just how far it extends, perpetuating internal distinctions between the unimpeachable "core" leadership of the Party, the "key minority" of elite decision makers and the broader membership at large. The further elaboration and incorporation of democratic centralism into the CCP's evolving institutionalized legal and disciplinary system thus side-steps, more than resolves, what Jean-Paul Sartre refers to as the "irreducible" contradiction inherent in the concept itself. ${ }^{80}$

\section{Acknowledgements}

The author wishes to thank $\mathrm{Hu}$ Yuhan, Tim Pringle and two anonymous reviewers for their generous comments, suggestions and assistance in editing this work.

\section{Conflicts of interest}

None.

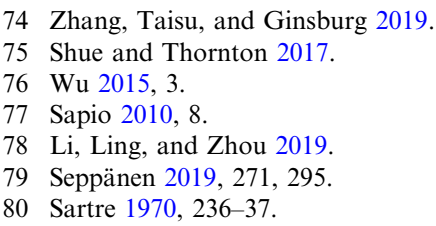




\title{
Biographical note
}

Patricia M. THORNTON is an associate professor of political science at the University of Oxford, and tutor in the politics of China at Merton College.

\begin{abstract}
摘要: 民主集中制作为列宁主义政党组织的标志, 在中国共产党的历史上 发挥了塑造性作用。尽管民主集中制被誉为“不可侵犯”与 “不变”的党的 原则, 但对该原则的理解却在其存在的一个世纪内, 发生了巨大的转变。 本研究追溯了这一概念在历次党章中的演变, 重点关注三个关键的历史时 刻: 将民主集中制作为组织原则正式写入党章的党的六大; 将整风作为党 的民主集中制的实践的党的七大; 将这一制度作为纪律工具从而树立了新 的里程碑的党的十九大。我认为, 虽然民主集中制体现了中国共产党的制 度可塑性和适应性治理, 并对于理解当代中国由党推动的宪政起到了至关 重要的作用, 但它也突显了内生于党的统治中不可解决的悖论。适应性并 不一定带来弹性。我的结论是, 中国共产党在习近平领导下的规范性无约 束的宪政外领导，突显了其非自由治理工作本质上与日益非理性的一面。
\end{abstract}

关键词: 中国共产党; 民主集中\#党章; 宪政; 党国; 党史

\section{References}

Angle, Stephen C. 2005. "Decent democratic centralism.” Political Theory 33(4), 518-546.

Backer, Larry Catá. 2009. "The Party as polity, the Communist Party, and the Chinese constitutional state: a theory of state-party constitutionalism.” Journal of Chinese and Comparative Law 16(1), 101-168.

Backer, Larry Catá. 2012. "Party, people, government and state: on constitutional values and the legitimacy of the Chinese state-party rule of law system." Boston University International Law Journal 30, 101-191.

Bai, Xin. 2021. "Hou yiqing shidai de "dong sheng xi jiang"” (The post-pandemic "rise of the East and decline of the West”). DW.com, 11 March, http://archive.today/GULmq.

Brødsgaard, Kjeld Erik. 2002. "Institutional reform and the bianzhi system in China." The China Quarterly 170, 361-386.

Dimitrov, Martin K. (ed.). 2013. Why Communism Did Not Collapse: Understanding Authoritarian Regime Resilience in Asia and Europe. New York: Cambridge University Press.

Gao, Hua, Stacy Mosher and Jian Guo. 2018. How the Red Sun Rose: The Origin and Development of the Yan'an Rectification Movement, 1930-1945. Hong Kong: The Chinese University of Hong Kong Press.

Guan, Huailun. 1996. “Zhonggong 'yida' gangling dishiyi tiao shi minzhu jizhong zhi” (Democratic centralism, the 11th article of the CCP First Congress's general programme). Lishi yanjiu 90, 48-58.

Han, Zhai 2020. The Constitutional Identity of Contemporary China: The Unitary System and Its Internal Logic. Leiden: Brill.

He, Fang. 2019. Dangshi biji: cong Zunyi huiyi dao Yan'an zhengfeng (Notes on the History of the Chinese Communist Party: From the Zunyi Conference to the Yan'an Rectification Movement). Hong Kong: City University of Hong Kong Press.

Heilmann, Sebastian, and Elizabeth J. Perry. 2011. "Embracing uncertainty: guerrilla policy style and adaptive governance in China." In Elizabeth J. Perry and Sebastian Heilmann, Mao's Invisible Hand: The Political Foundations of Adaptive Governance. Cambridge, MA: Harvard University Asia Center. 
Howland, Douglas. 2017. "Democratic centralism in revolutionary China: tensions within a people's democratic dictatorship." Open Journal of Philosophy 7(4), 448-466.

Jiang, Shigong. 2010. "Written and unwritten constitutions: a new approach to the study of constitutional government in China." Modern China 36(1), 12-46.

Jiang, Shigong. 2014. "Chinese-style constitutionalism: on Backer's Chinese party-state constitutionalism.” Modern China 40(2), 133-167.

Jiang, Shigong. 2015. "Dangzhang yu xianfa: duoyuan yiti fazhi gongheguo de jiangou" (The Party Constitution and State Constitution: the construction of a pluralistic unitary republican legal order). Wenhua zhongheng 4, 18-29.

Li, Li, and Peng Wang. 2019. "From institutional interaction to institutional integration: the National Supervisory Commission and China's new anti-corruption model." The China Quarterly 240, 967-989.

Li, Ling. 2015. "Rule of law' in a party-state: a conceptual interpretive framework of the constitutional reality of China." Asian Journal of Law and Society 2(1), 93-113.

Li, Ling. 2016. "The rise of the discipline and inspection commission, 1927-2012, anticorruption investigation and decision-making in the Chinese Communist Party." Modern China 42(5), 447-482.

Li, Ling. 2019. "Politics of anticorruption in China: paradigm change of the Party's disciplinary regime, 2012-2017.” Journal of Contemporary China 28(115), 47-63.

Li, Ling, and Wenzhang Zhou. 2019. "Governing the 'constitutional vacuum' federalism, rule of law, and Politburo politics in China." China Law and Society Review 4(1), 1-40.

Lin, Canchu, and Yueh-Ting Lee. 2013. "The constitutive rhetoric of democratic centralism: a thematic analysis of Mao's discourse on democracy." Journal of Contemporary China 22(79), 148-165.

Lin, Delia, and Susan Trevaskes. 2019. "Creating a virtuous leviathan: the Party, law, and socialist core values." Asian Journal of Law and Society 6(1), 41-66.

Liu, Shaoqi. 1945. "Guanyu xiugai dangzhang de baogao" (Report to the Seventh National Party Congress on revising the Party Constitution), http://www.71.cn/2015/0617/818012.shtml. Accessed 1 March 2021.

Mao, Zedong. 1938. “On the new stage.” In Stuart R. Schram (ed.). 2004. Mao's Road to Power, Volume VI. The New Stage, August 1937-1938. Armonk, NY: M.E. Sharpe, 458-541.

Mao, Zedong. 1962. "Talk at an enlarged working conference convened by the CCP Central Committee," 30 January, https://www.marxists.org/reference/archive/mao/selected-works/volume-8/ mswv8_62.htm. Accessed 6 March 2020.

Mertha, Andrew C. 2005. "China's 'soft' centralization: shifting tiaolkuai authority relations." The China Quarterly 184, 791-810.

Mertha, Andrew C. 2009. "Fragmented authoritarianism 2.0': political pluralization in the Chinese policy process." The China Quarterly 200, 995-1012.

Mertha, Andrew C. 2017. "'Stressing out': cadre calibration and affective proximity to the CCP in reform-era China." The China Quarterly 229, 64-85.

Nie, Chengjing. 2017. "Jiji tansuo shijian xingcheng baogui jingyan guojia jiancha tizhi gaige shidian qude shixiao - guojia jiancha tizhi gaige shidian gongzuo zongshu” (Active exploration and practice, formation of valuable experience, and the achievement of practical results the national supervision system pilot reform). Xinhuawang, 5 November, http://archive.today/Y9657.

Pei, Minxin. 2019. "Rewriting the rules of the Chinese party-state: Xi's progress in reinvigorating the CCP." China Leadership Monitor (June), https://www.prcleader.org/peiclm60.

Peng, Zhen. 1982. "Guanyu Zhonghua renmin gongheguo xianfa xiugai cao'an de baogao" (Report on drafting the revised PRC Constitution), 26 December, http://archive.today/uKjZj.

Pieke, Frank N. 2016. Knowing China: A Twenty-first Century Guide. Cambridge: Cambridge University Press.

Rong, Jingben, Yanming Luo and Daomeng Ye. 2004. Lun Yan'an de minzhu moshi: huayu moshi he tizhide bijiao yanjiu (On Yan'an's Democracy Model: A Comparative Study of Discursive Models and Institutions). Xi'an: Xibei University Press. 
Saich, Tony. 1985. "Through the past darkly: some new sources on the founding of the Chinese Communist Party." International Review of Social History 30(2), 167-182.

Sapio, Flora. 2010. Sovereign Power and the Law in China: Zones of Exception in the Criminal Justice System. Leiden: Brill.

Sapio, Flora. 2015. "Seeking truth from facts in Party discipline legislation." Paper presented at the Tenth Annual Conference of the European China Law Studies Association, Cologne, 25-27 September 2015.

Sartre, Jean-Paul. 1970. "Masses, spontaneity, party.” Socialist Register 7, 233-249.

Seppänen, Samuli. 2019. "Interrogating illiberalism through Chinese Communist Party regulations." Cornell International Law Journal 52(2), 267-312.

Shue, Vivienne. 1990. The Reach of the State: Sketches of the Chinese Body Politic. Stanford, CA: Stanford University Press.

Shue, Vivienne, and Patricia M. Thornton. 2017. "Beyond implicit dichotomies and linear models of political change in China." In Vivienne Shue and Patricia M. Thornton, To Govern China: Evolving Practices of Power. Cambridge: Cambridge University Press,1-26.

Smith, Stephen. 2000. A Road is Made: Communism in Shanghai, 1920-1927. Honolulu, HI: University of Hawai'i Press.

Snape, Holly. 2020. "New regulations for the Central Committee: codifying Xi era democratic centralism." China Law Translate, 1 December, https://www.chinalawtranslate.com/en/new-regulationsfor-the-central-committee-codifying-xi-era-democratic-centralism/.

Teiwes, Frederick C. 1993. Politics and Purges in China: Rectification and the Decline of Party Norms, 1950-65 (2nd ed.). Abingdon: Routledge.

van de Ven, Hans J. 1992. From Friend to Comrade: The Founding of the Chinese Communist Party, 1920-1927. Berkeley, CA: University of California Press.

Waller, Michael. 1981. Democratic Centralism: An Historical Commentary. Manchester: Manchester University Press.

Wu, Guoguang. 2015. China's Party Congress: Power, Legitimacy, and Institutional Manipulation. Cambridge: Cambridge University Press.

$\mathrm{Xi}$, Jinping. 2014. "Xi Jinping: guanyu 'Zhonggong zhongyang guanyu quanmian tuijin yifa zhiguo ruogan zhongda wentide jueding' de shuoming" (Xi Jinping: explanation concerning the "CCP Central Committee decision on some major questions in comprehensively moving forward the governing of the country according to law"). Xinhua, 28 October, http://archive.today/swSGg.

$\mathrm{Xi}$, Jinping. 2017. "Juesheng quanmian jiancheng xiaokang shehui duoqu xin shidai Zhongguo tese shehui zhuyi weida shengli" - zai Zhongguo gongchandang di shijiu ci quanguo daibiao dahui shang de baogao ("Secure a decisive victory in building a moderately prosperous society in all respects and strive for the great success of socialism with Chinese Characteristics for a new era" delivered at the 19th CCP National Congress). Gongchandang yuan wang, 10 October, http:/ archive.today/MGZKr.

$\mathrm{Xu}$, Tiancheng. 2019. "Minzhu jizhongzhi luoji de lishi xingcheng (1927-1929)" (The historical formation of the logic of democratic centralism (1927-1929)). Shanghai dangshi yu diangjian March, 8-12.

Xu, Xianming. 2017. "Gongchandang ji zai falü zhi zhong ye zai falü zhi xia hai zai falü zhi shang" (The Party is centred in the law, above the law, below the law). China Digital Times, 16 April, http://archive.today/jqXWw.

Yang, Fan. 2019. "The role of CPC regulations in Chinese judicial decisions: an empirical study based on published judgments." The China Review 19(2), 69-97.

Ye, Jianying. 1977. "Guanyu xiugai dangde zhang chengde baogao" (Report on revising the Party Constitution), 13 August, http://archive.today/4YbcA.

Young, Graham. 1984. "Control and style: discipline inspection commissions since the 11th Congress." The China Quarterly 97, 24-52.

Yu, Keping (ed.). 2010. Democracy and the Rule of Law in China. Leiden: Brill. 
72 The China Quarterly, 248, November 2021, pp. 52-72

Yuen, Samson. 2014. "Disciplining the Party: Xi Jinping's anti-corruption campaign and its limits." China Perspectives 3, 41-47.

Zhang, Taisu, and Tom Ginsburg. 2019. “China's turn toward law.” Virginia Journal of International Law 59, 306-389.

Zhang, Xiaodan. 2019. "Rule of law within the Chinese party-state and its recent tendencies." Hague Journal of Rule Law 9, 373-400.

$\mathrm{Zu}$, Jinyu, and Shenmiao Li. 2017. "Zhonggong erda yu dang de zhuzhi yuanze de zaoqi tansuo" (An exploration of the Second National Congress of the Communist Party of China and the Party's organizational principles in its early period). Lishi yanjiu (February), 129-133. 